Bozena Chovancova, Ph.D., Professor, Banking and International Finance Department, University of Economics in Bratislava,

Bratislava, Slovak Republic

Patrik Slobodnik, Internal doctoral student, Banking and International Finance Department, University of Economics in Bratislava,

Bratislava, Slovak Republic

\title{
THE IMPACT OF BREXIT ON COUNTRY RISK OF GREAT BRITAIN IN INVESTING AT STOCK MARKET
}

Great Britain is a significant financial centre in the world and its stock market has the major share of the world stock market. Changes at this market can largely influence investor behaviour, in particular as a result of the increased risk arising from the current situation. Higher risks at the stock market are reflected in the aggregate - the rise in price volatility, as well as lower liquidity of the market. The term "country risk" is currently associated with not only emerging markets but also advanced ones. Whereas in the past economic research has focused mainly on credit risk, or country insolvency at the sovereign bond market, country risk studies are currently also targeting stock markets where the investor may encounter even higher risk. The purpose of this paper is to examine the sensitivity of the stock market movement to the UK's political risks linked to the Brexit, which may have consequences not only for the country, but for the whole of Europe. This fact must be considered by every investor when deciding about investment allocation into this country. At the same time, we will try to look at possible changes at the UK stock market from the outlook for the Industry 4.0, which in turn can positively influence the stock market. The results of analysis of stock indexes volatility FTSE100, DAX30 i S \& P500 during the 2015-2017 years showed that political decisions on Brexit didn't had significant impact on the negative developing tendency of the stock market. In the paper, the authors proved the impact of the sectorial structure and export policy on the Country Risk and possibilities its changes as a result of the Industry 4.0 implementation. The issue of the future is debatable, where the decisive idea of a new industrial revolution and the need for a change in sectoral structures will also be reflected in the structure of stock markets.

Keywords: country risk, economic risk, political risk, financial risk, volatility of stock market, risk spread, Great Britain, Brexit.

Introduction. The term "country risk" as a category includes not only economical but also political and financial risks. Nowadays we can find several methods to measure equity risk in each country. The International Country Risk Guide (ICRG) is the resulting category of measuring the country risk. ICRG, with its basis scoring, determines the level of risk at the country's stock market. The ICRG index has a subset of other indices: the Economic Risk Index (ER), the Political Risk Index (PR) and the Financial Risk Index (FR). The economic risk index measures the macroeconomic indicators such as GDP per capita, economic growth (GDP growth in \%, annual inflation rate, state budget deficit and debt ratio relative to GDP) or the balance of payments, while the political risk index takes into account the stability of government, internal and external conflicts, the level of corruption, the level of judiciary system and law, level of international relations, external conflicts etc. The ICRG also measures financial risk through such indicators such as foreign debt (\% of GDP), foreign debt in relation to exports, exchange rate and so on.

These factors are also part of the well-known ratings, provided by reputable rating agencies worldwide. Generally speaking, country risk covers a complex of problems that are often analysed as partial 
quantities, quantified by different statistical methods and econometric models. Many renowned economists quantify risk using different econometric methods, through risk spreads, as applied not only to the bond market but also to the stock market.

Literature review. The publications of foreign and domestic authors currently encounter with the fact that specifically examines the country risk separately for the bond market and the stock market. The country risk associated to the bond market is mainly focused on the credit risk or the insolvency of the country. Kerstin Bernoth, Jürgen von Hagen and Ludger Schuknecht (2012) stated that this risk is measured and quantified as a risk premium. Much attention was given to this issue especially in connection with the insolvency of Greece. Dionysios Chionis, loannis Pragidis and Panagiotis Schizas (2014) examined the impact of macroeconomic indicators to the government bond yields and growth of risk margins in Greece.

At the present, we come across the working papers, which deals with the problems of the country risk associated to the stock market. In this area, Abdulaziz I. Almahmound (2014) offered an interesting point of view that examines the relationship between country risk rating and volatility of the stock market in Saudi Arabia.

Turan G.Bli and Nusret Cakici (2010) dealt with the problem of the world market risk of the stock market. Additionally, they used International Capital Pricing Model (ICAPM) for country-specific risk. The results of their research are also important in creating an optimal equity portfolio with regard to the countryspecific risk. The stock market of Latin American is also in the centre of attention. Ephraim Clark and Konstantinos Kassimatis (2004) monitored the behaviour of Latin America's largest stock markets (Argentina, Brazil, Chile, Colombia, Mexico and Venezuela) and quantified the level of country risk and risk margins.

In advance, Marc L. Ross (2016), Simionescu et al. (2018) and Strielkowski et al. (2016) responded to some of the expected economic consequences of Brexit, giving some advantages but also the disadvantages and the risks of this process. Many authors payed attention to the emerging market risk premium, with particular emphasis on low-income economies. Naumoski Aleksandar, Arsov Saso, Gaber Stevan and Naumovska Vasika Gaber (2016) quantified the risk premium on the Macedonian stock market.

Autors Chang, Chen and Zolotoy (2017) investigated the relation between the stock market liquidity and the risk of a price crash.

Relatively considerable attention was given to this issue by the well-known economist Aswath Damodaran (2003), who regularly evaluated the level of risk of individual countries in both bond and equity markets. Attention was also given to his well-known book publications dealing with credit default swaps or risk margins on the stock markets, including stock valuation in individual regions.

The approach of the authors Miloš Bikár and Martin Hodula (2016) is also interesting. They tried to prove through the Bayesian vector regression model (BAVR) that the changes in the values of the stock indices DAX 30 and FTSE 100 significantly affect the changes of the macroeconomic environment. The article by Czech authors Marika Křepelová and Jozef Jablonský (2013), who used Markov's model, proves that under the conditions of the Czech capital market, the volatility of the stock market is also conditioned by changes in the bond market.

Authors Lopez-Espinosa, Rubia, Valderrama and Moreno, A. (2016) provide a new measure of sovereign country risk exposure (SCRE) to global sovereign tail risk, which is based on information incorporated in 5-year sovereign CDS spreads. In the article created by Scholl (2017) we can find a new stochastic dynamic politico-economic model of sovereign debt, which analyse the interaction of sovereign default risk and political turnover.

Cepni (2017) identified the macroeconomic factors which influence the sensitivity of credit default swap premium to changes in the global risk factors across emerging markets. The exact evaluation of sovereign 
disaster risk finance instruments available to governments for funding disaster loses, we can find in paper by Clarke, Mahul and Poulter (2017). In working paper created by Fry, John and Brint (2017) we find developed financial model to investigate whether bubbles present in opinion polls and betting markets prior to the UK's vote on EU membership on 23 June 2016. Some authors also look at the links between various stock market anomalies in association with the risk on the stock market. Peter Árendás (2017) quantified these anomalies using the so-called Halloween Effect.

The contribution from Desmet, K. and Parente, S.L. (2012) is associated with new trends in the stock markets. The authors also highlight the impact on the future economic growth. In recent study, authors Yevsikov, I.A., Korovin, K.O., Sarygulov, A.I. (2017) also give attention to the need to restructure welfare, which will undoubtedly have an impact on the stock markets as well

Methodology. Currently, the Brexit issue is significantly affecting the stock market mechanism in the UK. As part of our research, we looked at the historical growth of risk margins on the stock market as well as the risks of the country. We used the historical data, which were processed by A. Damodaran since the early 20th century. We compared the obtained data with the developed stock markets of the world such as the US and Germany. From the point of view of the political risk of Great Britain, the decisive period for us was 2015-2017. For our analysis and comparison, we worked with the data FTSE, DAX, and S\&P500 on a monthly basis. We illustrated these connections in the form of a graph.

Additionally, we quantified the size of the risk premium on the UK stock market and the country risk for the investor investing in this market. For this purpose, we used data on a weekly basis. We used the following relationships to quantify these variables:

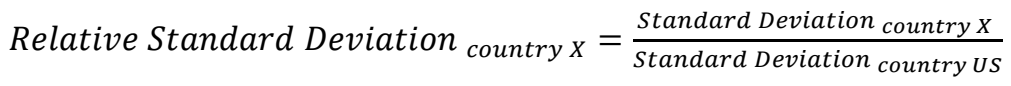

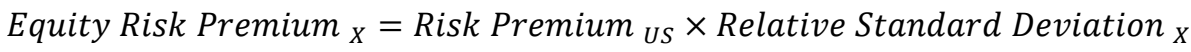

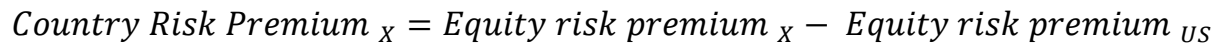

Firstly, we presented a historical overview of the volatility of the FTSE, DAX, and S\&P 500 indices from 1900-2016 to assess the level of risk on the UK stock market and also, the standard deviation, which was used for calculating the risk premium of the stock market. The calculation of risk premium is linked to the US stock market, which is also the basis for the country risk calculation. We had also put into the analysis the German market, which currently represents the most efficient stock market within the European Union. When calculating the UK risk margin, we started from the period just after the referendum (July 2017). For a more objective assessment of the expected changes, we monitored the risk premium and country risk in the three countries for the 2015 pre-referendum period and subsequently after the 2016 decision. In the light of the ongoing legislative processes, we also used the data for the first half of 2017.

Based on these relationships and the assumption that Brexit as a political decision will also influence the economic area, we can set up a hypothesis:

1. Before the referendum, the volatility of the FTSE was lower, indicating that even the risk premium was lower. The Brexit decision increases the risk margin

Derogations will be quantified for the period 2015-2017. When processing individual database data, we relied on official sources of stock exchanges in the countries concerned. The interest in this research area also led us to analyse future changes in the sectoral GDP structures as well as stock market structure in the UK, especially after a definitive exit from the European Community. In solving this issue, the following theoretical question appears:

2. Can the current structure of the UK's GDP ensure economic growth in the future, and will this GDP 
structure increase equity risk?

We start from the future development of scientific and technical innovations brought by Industry 4.0 and expected changes in the economy and the stock markets. In the processing, analysis and quantification of individual data, we use official data from the statistical bureau of the UK, the Eurostat database and the ECB, as well as from stock exchange of the countries, which are subject of our comparison.

Results. For analysing the stock market growth in UK and calculating the risk margins, we used historical data from 1900-2016. In the first part of the following table, we can see a risk premium as the difference between the return on shares and the short-term government securities of T-Bills. In the second part, we can see the risk premium as the difference between the shares and the long-term government securities of G-Bonds. The basis for comparison was the aforementioned countries of the US and Germany.

Table 1 - Historical Risk Premiums across Equity Market 1900-2016 (in \%) (based on Credit Suisse Global Investment Returns Sourcebook, 2016)

\begin{tabular}{|l|c|c|c|c|c|c|c|c|}
\hline & \multicolumn{4}{|c|}{ Stock minus Short term Governments } & \multicolumn{3}{c|}{ Stock minus Long term Governments } \\
\hline Country & $\begin{array}{c}\text { Geometric } \\
\text { Mean }\end{array}$ & $\begin{array}{c}\text { Arithmetic } \\
\text { Mean }\end{array}$ & $\begin{array}{c}\text { Standard } \\
\text { Error }\end{array}$ & $\begin{array}{c}\text { Standard } \\
\text { Deviation }\end{array}$ & $\begin{array}{c}\text { Geometric } \\
\text { Mean }\end{array}$ & $\begin{array}{c}\text { Arithmetic } \\
\text { Mean }\end{array}$ & $\begin{array}{c}\text { Standard } \\
\text { Error }\end{array}$ & $\begin{array}{c}\text { Standard } \\
\text { Deviation }\end{array}$ \\
\hline USA & $5,5 \%$ & $7,4 \%$ & $1,8 \%$ & $19,6 \%$ & $4,3 \%$ & $6,4 \%$ & $1,9 \%$ & $20,8 \%$ \\
\hline UK & $4,4 \%$ & $6,1 \%$ & $1,8 \%$ & $19,5 \%$ & $3,6 \%$ & $4,9 \%$ & $1,6 \%$ & $17,1 \%$ \\
\hline Germany & $6,1 \%$ & $9,9 \%$ & $2,9 \%$ & $31,2 \%$ & $5,0 \%$ & $8,4 \%$ & $2,6 \%$ & $28,3 \%$ \\
\hline
\end{tabular}

On the next graph, we can see that the UK, compared to the US, has only minor volatility of risk premiums of stock market in the period from 1900-2016. It is also clear that risk premiums, compared to the government bonds, are even significantly lower than in the US.

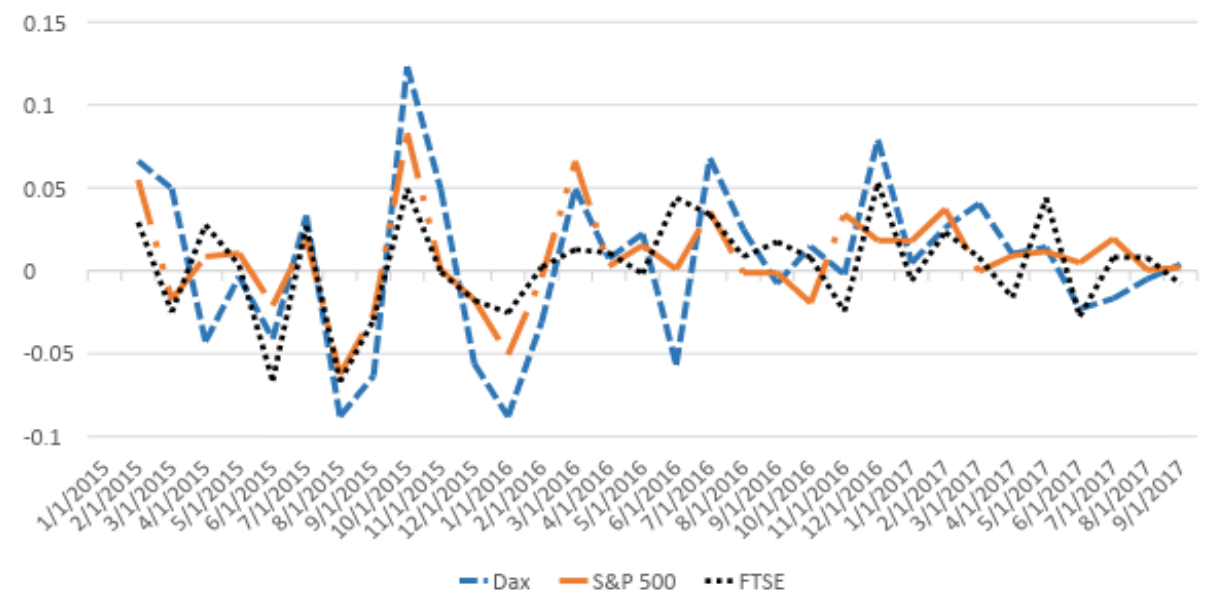

Figure 1 - Volatility of stock indices FTSE100, DAX 30 and S\&P500 in years (2015-2017) (based on own processing www.investing.com)

Germany's stock market has a higher risk premium compared to the UK or the US market. However, it is necessary to recall that Germany's stock market does not have such a long history as other countries. In addition, after World War II, Germany had to build his economy and market from its foundations. In the 1990s, Germany performed an extensive restructuring of the economy, particularly in connection with its 
unification.

We analysed the volatility of stock market indices FTSE100, DAX30 and S\&P500 in the years 20152017 (in the period of preparation for referendum about Brexit, where decisions and preparations to leave the EU was made). It can be hardly said that this political decision increased the volatility of stock index FTSE 100. Substantially higher volatility was seen not only on the DAX 30 but also on the S\&P index.

The light increase of volatility of FTSE can be tracked exactly at the time of the referendum (June 2016), but these market fluctuations are comparable to other months. But the question is how the risk margin respectively indicator of country risk reacts to this situation.

Relative Standard Deviation $_{\text {country } U K}=\frac{\text { Standard Deviation }_{\text {country } U K_{K}}}{\text { Standard Deviation }_{\text {country US }}}=\frac{22,8 \%}{20,8 \%}=1,1 \%$

Equity Risk Premium $_{U K}=$ Risk Premium $_{U S} \times$ Relative Standard Deviation $_{U K}=$ $5,69 \% \times 1,1 \%=6,25 \%$

Country Risk Premium $_{U K}=$ Equity risk premium $_{U K}-$ Equity risk premium $_{U S}=$ $6,25 \%-5,69 \%=0,56 \%$

These calculations are related to the period immediately after the referendum (July 2016). For a more objective assessment of the growth of risk premiums before and after the referendum, we give the following table, where we provide figures for 2015, 2016 and 2017 (only data for the first half of 2017 can be reported within this year).

Table 2 - Equity and Country Risk Premium in 2015-2017 (based on pages.stern.nyu.edu/adamodar/New_Home_Page/)

\begin{tabular}{|l|c|c|c|c|c|c|}
\hline & \multicolumn{2}{|c|}{2015} & \multicolumn{2}{c|}{2016} & \multicolumn{2}{c|}{2017} \\
\hline Country & $\begin{array}{c}\text { Total Equity } \\
\text { Risk Premium }\end{array}$ & $\begin{array}{c}\text { Country Risk } \\
\text { Premium }\end{array}$ & $\begin{array}{c}\text { Total Equity Risk } \\
\text { Premium }\end{array}$ & $\begin{array}{c}\text { Country Risk } \\
\text { Premium }\end{array}$ & $\begin{array}{c}\text { Total Equity Risk } \\
\text { Premium }\end{array}$ & $\begin{array}{c}\text { Country Risk } \\
\text { Premium }\end{array}$ \\
\hline UK & 6,44 & 0,69 & 6,82 & 0,57 & 5,97 & 0,28 \\
\hline USA & 5,75 & 0,00 & 6,25 & 0,00 & 5,69 & 0,00 \\
\hline Germany & 6,40 & 0,65 & 6,31 & 0,06 & 5,76 & 0,07 \\
\hline
\end{tabular}

At the end of 2015 , the risk premium of the UK was $6.44 \%$ and of the US was $5.75 \%$, which means that the country risk premium was $0.69 \%$ (Damodaran, A., 2016). Despite a major political decision, the UK country risk premium did not change significantly and was only $0.57 \%$ at the end of 2016 . The first half of this year shows that there was a significant decline in the country risk premium in the UK to $0.28 \%$. An even more pronounced decline occurred in Germany; the country risk premium stood at $0.65 \%$ in 2015 and dropped to $0.07 \%$ in the first half of 2017. In other words, in the US and Germany, there was a fall in the risk margin, which was obviously the result of favourable economic growth in the countries concerned.

Country risk from the perspective of industry structures and export policy. The economy of the UK is mainly supported by domestic demand. The main driving force behind GDP growth is private investment and private consumption, while public spending has been curtailed in recent years. Economic growth in the last two decades has been associated mainly with the services sector, which represents the largest share of the GDP. The Office for National Statistics UK (ONS) reports $3 / 4$ of services on the GDP of the country.

It is also a strong exporter of services, especially those that are linked to the financial sector (financial services) and information technology (IT). On the other hand, import is also in a stable deficit due to domestic consumption. London is one of the three largest financial centres in the world, therefore domestic businesses have easier access to external financial resources compared in other countries in the world. 
Availability of credit and other investment opportunities are a well-known factor in the country's economic performance. These are the reasons why GB managed the 2008 financial crisis and its consequences much faster than other EU countries.

This is confirmed by our calculations of risk spreads for investors in the UK stock market. The reason for investing in the stock market was the economic growth of the UK, which in recent years has also secured a fall in risk margins for investors and also wasn't affected by the changes in the Brexit referendum. Paradoxically, we saw the adverse development of risk margins compared to sovereign rating, which has fallen by one degree.

As Yearbook 2017 Credit Suisse Global Investment Returns reports, London is also ranked among the best performing financial centres in the world today. It is a global banking centre with 580 international banks and 170 global banks. At the same time, it has the largest foreign exchange market in the world. The Equity Market also corresponds to the third place in the world. Globally known companies with a high market capitalization such as HSBC, BP, British American Tobacco, Glaxo SmithKline, Astra Zeneca and others are parts of this equity market. The bond market also has a significant fourth place in the world. It is also the largest fund management centre in the world, managing almost half of institutional capital and more than $3 / 4$ of European hedge fund assets. London is at the same time the main trading centre for commodities, shipping and other services. The sectoral structure of the stock market in the UK (FTSE 100) also reflects a large share of services, especially financial services. According to the Industry Classification Benchmark (ICB Ground Rules), which lists 10 sectors in the stock market structure index of the FTSE 100 index, the following composition of the index is.

Table 3 - Structure of the FTSE 100 stock index (June 2017) (Industry Classification Benchmark: Structural enhancements to the industry categorization framework 2017)

\begin{tabular}{|l|c|}
\hline Sector & share in $\%$ \\
\hline Technology & 12,8 \\
\hline Telecommunications & 4,8 \\
\hline Health Care & 11,2 \\
\hline Financials & 19,6 \\
\hline Real Estate & 4,0 \\
\hline Consumer Staples & 8,2 \\
\hline Industrials & 12,4 \\
\hline Basic Materials & 4,8 \\
\hline Energy & 6,0 \\
\hline Utilities & 3,4 \\
\hline Total & 100 \\
\hline
\end{tabular}

As we can see in the table above, the largest share of the UK stock market has financial services, which are followed by new technologies. A relatively large share is represented by Industrials and Health care. The share of Health, which has generally growing tendency in the world, we can expect to grow significantly in the UK stock market in the future. UK financial sector acted as an intermediary financial service between North America and Europe, therefore we can expect decline of share of financial services. Many economists refer to the UK as a "post-industrial economy" because of dominant activities associated with IT. They also point out that the share of industrial production has declined significantly in the last 50 years by only around $12 \%$.

If we assume that even the UK economy has a pro-export character, which is manifested mainly in the area of services and thus financial services, in the case of Brexit we can expect restrictions in the area of providing financial services, respectively growth of barriers in providing of financial services. This would result in a stock market fall, where financial services have a strong share.

We assume that the UK will also undertake extensive restructuring of the economy, focusing on the 
requirements of Industry 4.0. With the rise of Industry 4.0, economists also expect the downturn in industry to be halted as a sector in both GDP and equity markets. The automatization of industrial production will require more educated people. The need of new types of materials, components, construction of whole robots will require synergy with sophisticated IT as well as engineering specialists. It is also possible to expect the growth of machinery that will work with the latest technologies.

As in the 1990s, new services emerged with the onset of the technological revolution, the emergence of a new high - tech wave may also result in the emergence of new services that will be coupled with a significant shift of labour. Positive growth can bring new IT and health care in connection with Industry 4.0 processes. The growth of these sectors in the future can compensate for a reduction in the share of financial services in the stock market.

Conclusion. Research on Country Risk shows that generally accepted rules that have demonstrated the growth of risk in the stock market in connection with some political risks may not always be true. The political decision - exit the UK from the EU motivated us to investigate if this decision will affect the size of the stock market risk. We have measured this risk through risk margins. Immediately after Brexit, rating agencies also lowered the UK rating, which could be expected to increase risk in the form of risk margins on the stock market.

Looking at the volatility of the FTSE 100 stock index and calculating the risk margins on the UK equity market, we came to the surprising conclusion that the political decision did not affect the negative development of the stock market, on the contrary, the risk margin declined. Looking more closely at the development of the UK economy, we have concluded that the rapid development of the economy after the 2008 crisis and the subsequent economic growth with a pro-export policy has contributed much to the positive development of risk margins. This has also been reflected in the development of the FTSE 100 stock index, which has seen significant growth.

A major challenge for the UK is also the 4th Industrial Revolution, which will also require structural changes in the economy that will surely react in the future to the stock market as well. It can be assumed that the financial services industry will lose its prominent position on the stock market and broadly diversified IT services along with health who will gain a privileged position.

Previous research has shown that the country risk of each country is necessary to examine in association of the various factors that affect stock market risk. The UK stock market has investor's confidence, but also it has built-in stabilizers that do not even raise the risk for the investor even under serious political decisions. The issue of the future is debatable, where the decisive idea of a new industrial revolution and the need for a change in sectoral structures will also be reflected in the structure of stock markets.

Acknowledgment. This contribution is the result for the project VEGA (1/0009/17) "The making of the Capital union in Europe and its impact on individual member countries ".

Abdulaziz I. and Almahmound, A.I. (2014). Country Risk Ratings and Stock Market Movements: Evidence from Emerging Economy, International Journal of Economics and Finance, Vol.6, No.10.

Árendáš P. (2017): The Halloween Effect on Financial Markets, 1sted. Prague, Czech Republic, Walters Kluwer 2017.

Bali,T.G. and Cakici,N. (2010). World market risk, country-specific risk and expected returns in intenational stock markets, Journal of Banking and Finance 34 .

[Bernoth,K., Hagen, J. and Schuknecht, L.: (2012). Sovereign risk premiums in the European government bond markets, Journal of International Money and Finance 31.

Bikár, M. and Hodula, M. (2016). Stock Market Indices Modelling by a Small Scale Bayesian VAR: The Case of British FTSE and German DAX Index., Ekonomický časopis No8, 64/2016.

Cepni, O., Kucuksarac, D., and Yilmaz, M. H. (2017). The sensitivity of credit default swap premium to global risk factor: Evidence from emerging markets. Economics Letters 2017, vol.159, p74-77.

Clark, E. and Kassimatis, K. (2004). Country financial risk and stock market performance: the case of Latin America, Journal of Economics and Business 56 


\section{B. Chovancova, P. Slobodnik. The Impact of Brexit on Country Risk of Great Britain in Investing at Stock Market}

Clarke, D., Mahul, O. and Poulter, R. (2017). Evaluating Sovereign Disaster Risk Finance Strategies? A framework, The Geneva Papers on Risk and Insurance - Issues and Practice 2017, vol. 42, p.565.

Damodaran, A. (2003). Country Risk and Company Exposure: Theory and Practice, Journal of Applied Finance Fall/Winter 2003

Damodaran, A. (2016): Equity Risk Premiums, Stern School of Business.

Desmet, K., Parente, S.L. (2012). The evolution of markets and the revolution of industry: a unified theory of growth, Journal Economic Growth.

Chionis, D., Pragidis , I and Schizas, P (2014): Long-term government bond yields and macroeconomic fundamentals: Evidence for Greece during the crisis-era, Finance Research Letters Vo11, Issue 3.

Fry, J., and Brint, A. (2017). Bubbles, Blind-Spots and Brexit. Risks 2017, vol. 5, no. 3, p.37.

Křepelová, M. and Jablonský, J (2013). Analýza státních dluhopisu jako indikátoru pro akciový trh, Politická ekonomie Vol.61, No 5.

López-Espinosa, G., Moreno, A., Rubia, A., \& Valderrama, L. (2017). Sovereign tail risk. Journal of International Money and Finance 2017, 79, 174-188.

Naumoski Aleksandar, Arsov Saso, Gaber Stevan, Naumovska Vasika Gaber (2016). Expected Equity Risk Premium: Survey Approach in the Case of a Small Emerging Market, Research Journal of Finance and Accounting, Vol.7, No2.

Ross,M.L. (2016): Britain's Post-Brexit Options: Alternative Lifestyles (Digest Summary), Financial Analysts Journal, February 2016, Vo 46. Issue2.

Simionescu, M., Bilan, Y., Smrčka, L., \& Vincúrová, Z. (2017). The effects of European Oeconomic integration and the impact of BREXIT on the UK immigrants from the CEE countries. E+ M Ekonomie a Management. 20(1), 29-4.7

Scholl, A. (2017). The dynamics of sovereign default risk and political turnover. Journal of International Economics 2017, 108 37-53.

Strielkowski, W., Tumanyan, Y., Kalyugina, S. (2016). Labour Market Inclusion of International Protection Applicants and Beneficiaries, Economics and Sociology, 9(2), 293-302. DOI: 10.14254/2071-789X.2016/9-2/20.

Yevsikov, I.A., Korovin, K.O., Sarygulov, A.I. (2017). Modern Trends in Evaluation of Macroeconomic Structural Changes, in: 'Studies on Entrepreneurship, Structural Change and Industrial Dynamics.

Credit Szusse Global Investment Returns, Research Institute, Yearbook 2017, Summary Edition

Б. Чованкова, Ph.D., профессор, Університет економіки в Братиславі (Братислава, Словаччина);

П. Слободник, докторант, Університет економіки в Братиславі (Братислава, Словаччина).

Вплив Brexit на «ризик країни» для Великобританії: інвестиційні процеси на фондовому ринку

Великобританія є потужним фрінансовим центром, що обслуговує значну частку операцій світового фрондового ринку. Розпочаті процеси Вrexit обумовлюють появу нових ризиків на фондовому ринку цієї країни, що значною мірою впливає на поведінку інвесторів, зростання волатильності цін, а також зниження ліквідності фондового ринку. Результати аналізу наукової літератури свідчать, що «ризик країни» $є$ важливою детермінантою глобальної конкурентоспроможності не лише для країн що розвиваються, а й для розвинутих. В статті обгрунтовано, що поряд з традиційними методами дослідження «ризику країни», які в основному зосереджувалися на оцінюванні кредитних ризиків або ризиків неплатоспроможності країни на ринку державних облігацій, на сучасному етапі набуває актуальності врахування також і інвестиційних ризиків, які обумовлюють суттєві транссоормації на фондовому ринку. Метою даного дослідження є вивчення чутливості змін на фондовому ринку внаслідок розпочатих процесів виходу Великобританії з ЄС, які можуть мати наслідки не тільки для конкурентоспроможності даної країни, але і для всієї Європи. Зазначено необхідність врахування політичних ризиків Великобританії, пов'язаних з Brexit, при прийняттяя інституційними інвесторами рішень щодо спрямування ресурсів в економіку країни. Також авторами аналізуються вплив Industry 4.0 на розвиток фондового ринку. Результати дослідження волатильності фоондових індексів FTSE100, DAX30 i S \& P500 в 20152017 роках свідчать, що політичне рішення Великобританії щодо виходу з ЄС в иілому не вплинуло негативно на розвиток фондового ринку країни, а навіть призвело до зниження інвестиційного ризику. В роботі підтверджено вплие галузевої структури і експортної політики держави на рівень «ризику країни» та можливості його змін внаслідок впровадження Industry 4.0.

Ключові слова: ризик країни, економічний ризик, політичний ризик, фінансовий ризик, нестабільність фондового ринку, ризиковий спред, Великобританія, Brexit. 